\title{
A ARTE POÉTICA DE CARLOS DRUMMOND DE ANDRADE
}

\section{Edna Maria Porto}

Este é o ano em que comemoramos o centenário de nascimento do grande poeta brasileiro Carlos Drummond de Andrade. Muitos são os que se referem a Drummond chamando-o de poeta da contemporaneidade. Encontro nesta palavra uma indicação do efeito que se produz na poesia drummondiana, a qual, ao referir-se quase sempre ao mais simples e cotidiano do vivido do homem Drummond termina por produzir um encontro com o vivido de cada homem, de modo que ler Drummomnd é, sobretudo, encontra-lo e encontrar-se em suas palavras.

Sabemos que a obra de arte produz uma interrogante convergência entre o particular e o universal, convergência que se funda numa inserção absolutamente singular, pois ao tempo que o objeto artístico impressiona a muitos, ele o faz de maneira completamente única a cada um, falando a essa nossa dimensão secreta, essencialmente ocultada de nós mesmos, irredutivelmente não sabida e, ao mesmo tempo fonte, de todo saber.

Esta dimensão enigmática do objeto de arte tem produzido efeitos que convém situar. Tornou-se um tanto freqüente que para a questão não formulada que se instala diante do objeto de arte busquem-se respostas na vida do autor.

Se, por um lado, isto evidencia quanto o não-sabido exige articulação, ao mesmo tempo coloca-nos numa posição especular bastante inicial frente ao objeto de arte, como se diante do espelho buscássemos, às suas costas, a verdade da imagem que nele miramos. Embora tal abordagem não se limite à arte literária, encontramos, neste âmbito, um sem número de esforços para atingir o para-além do dito imediato, daquilo que se nos apresenta como enigma, a partir das palavras com as quais o autor compõe sua obra.

Os instrumentos psicanalíticos têm sido bastante requisitados para tais investigações, tornando-se ferramenta preciosa neste tipo de investida "clínica". Seguindo por este mesmo caminho também são 
produzidas, sem muita dificuldade, interpretações elaboradas das obras de arte, fornecendo minuciosas explicações "edípicas" para os elementos determinantes de sua construção.

Todavia, em não sendo este o caminho através do qual psicanálise e arte se interrogam mutuamente, de que modo estes dois campos da produção humana podem dialogar acerca do tecido humano, do qual são construções privilegiadas?

$\mathrm{Na}$ orelha de sua antologia poética Carlos Drummond de Andrade apresenta a si mesmo e à sua poesia, e o faz de modo muito simples e direto.

Nasci em Itabira, Minas Gerais, e o meio físico e social de minha terra marcou-me profundamente. Ganhei a vida como funcionário público e jornalista. Dediquei-me à literatura por prazer. Fui muito criticado e ridicularizado quando jovem. Atualmente a maioria das opiniões é favorável à minha poesia. Não tenho a pretensão de ser mestre em coisa alguma e conheço minhas limitações. Depois de praticar a literatura por mais de 60 anos, continuo acreditando, com o mesmo fervor, na beleza da palavra e no texto elaborado com arte. Acho que a literatura, tal como as artes plásticas e a música, é uma das grandes consolações da vida, e um dos modos de elevação do ser humano sobre a precariedade de sua condição.

Neste ponto vale lembrar uma frase de outro poeta eminente, Octavio Paz, quando diz que um escritor não tem biografia, sua biografia é sua obra!

Poeta do cotidiano, profundamente imagético em seu estilo, o mineiro Drummond, mineiramente, como não poderia deixar de ser, escreveu sobre a singeleza da vida, referindo-se, por exemplo, às desventuras do menino, como em : 
Terceiro Dia

Mamãe, quero voltar.

Imediatamente.

Diz a Papai que venha me buscar.

Não fico aqui, Mamãe, é impossível.

Eu fujo ou não sei não, mas é tão duro

Este infinito espaço ultrafechado.

Esta montanha aqui eu não entendo.

Essas caras não são caras da gente.

E faz um frio e tem jardins fantásticos mas sem

O monsenhor, beijo, a crisandália

Que são nossos retratos de jardim.

Da comida não me queixo, é regular,

Mas falta minha xícara, guardou

Para quando eu voltar?

Ai Mamãe, minha mãe, o travesseiro

Eu ensopei de lágrimas ardentes

E se durmo é um sonhar de estar em casa

Que a sineta corta ao meio feito pão:

Hora de banho madrugadora

De chuveiro gelado, todo mundo.

Nunca tomei banho assim, sou infeliz

Longe de minhas coisas, meu chinelo,

Meu sono só meu, não nesta estepe

De dormitório que parece um hospital.

Mamãe, o dia passou mas tão comprido

Que não acaba nunca de passar.

Um ano à minha frente? Não agüento.

Mas farei o impossível. Me abençoe.

E faz um frio... A caneta está gelada.

Não te mando esta carta

Que um padre leria certamente

E me põe de castigo uma semana.

(e nem tenho coragem de escrever).

Esta carta é só pensada.

Sobre os revezes do amar, muitas vezes, como em: 


\title{
Memória
}

\author{
Amar o perdido \\ Deixa confundido \\ Este coração. \\ Nada pode o olvido \\ Contra o sem sentido \\ Apelo do não. \\ As coisas tangíveis \\ Tornam-se insensíveis \\ à palma da mão. \\ Mas as coisas findas, \\ Muito mais que lindas \\ Essas ficarão.
}

Sobre sua terra natal, em:

Confidência de Itabirano

Alguns anos vivi em Itabira.

Principalmente nasci em Itabira.

Por isso sou triste, orgulhoso: de ferro.

Noventa por cento de ferro nas calçadas.

Oitenta por cento de ferro nas almas.

E esse alheamento do que na vida é porosidade e comunicação.

A vontade de amar, que me paralisa o trabalho,

Vem de Itabira, de suas noites brancas, sem mulheres

E sem horizontes.

E o hábito de sofrer, que tanto me diverte,

É doce herança itabirana. 
Do amor outonal, em:

Campo de flores

Deus me deu um amor no tempo da madureza,

Quando os frutos ou não são colhidos ou sabem a verme.

Deus - ou foi talvez o Diabo - deu-me este amor maduro,

$\mathrm{E}$ a um e outro agradeço, pois que tenho um amor.

Sobre a morte, em:

Versos à boca da noite

Sinto que o tempo sobre mim abate

Sua mão pesada. Rugas, dentes, calva

Uma aceitação maior de tudo,

E o medo de novas descobertas.

E, em "De arredio motel em colcha de Damasco", ele leva ainda mais longe esse dizer-se:

De arredio motel em colcha de damasco

Viste em mim teu pai morto, e brincamos de incesto.

A morte, entre nós dois, tinha parte no coito.

O brinco era violento, misto de gozo e asco,

E nunca mais, depois, nos fitamos no rosto.

Se toda escrita é inarredavelmente referida ao seu autor, Drummond parece levar isto às últimas conseqüências, assumindo em seu escrito um estilo profundamente testemunhal, quase sempre situando o tema de seus poemas no espaço do privado e, por vezes, pode-se mesmo dizer, do espaço mais íntimo.

Aqui podemos levantar uma primeira questão:

Qual a relação do poeta à imagem que lhe permite ultrapassar o limite diante do qual o falante previsivelmente estanca, pelo temor de que possa não ser conforme à imagem que o Outro espera?

Sabemos o quanto o sujeito resvala e muitas vezes se renega diante do olhar do Outro, na procura de uma imagem, ainda que 
muitas vezes à custa de sua desqualificação como falante. Ser conforme o idealizado no outro constitui um tempo importante da constituição do sujeito.

Uma segunda questão que se produz é qual a relação do poeta com a linguagem que lhe permite mais uma vez atravessar um liame que faz com que a palavra seja temida pelo falante, seja pelo que ela pode dizer, seja pelo que ele pode não articular, gaguejar e aí fazer ouvir o que é próprio ao inconsciente, essa parcela de inaudito, nosso bem mais precioso, que não pode existir senão na medida em que permaneça essencialmente oculto, isto é, não-sabido de todo saber exterior?

Poderíamos rapidamente responder que o poeta é conhecedor de que não somos constituídos pelo domínio do que pensamos e sim pelo que dizemos, já que a partir do momento em que um sujeito se permite falar descobre que a palavra dispõe de um poder criador, capaz de produzir articulações inéditas. Mas é a palavra que dispõe desse poder, e não o sujeito.

O psicanalista conhece esse efeito de atravessamento do ponto em que a palavra cessa de ser temida em seu poder criador. Ponto no qual não se está mais cativo da imagem porque, para além dela, conquistou-se a palavra.

Todavia, o que asseguraria ao poeta que este não seria devassado por um olhar que lhe invadisse o que há de mais íntimo e velado?

Aqui devemos reconhecer que, longe de pôr o inaudito ao alcance do que é propriamente audível e visível, o poeta, por sua palavra, em sua arte, encarna a radicalidade mesma do campo do nãosaber, do que permanece irredutivelmente enigmático, o qual a arte poética, ao bordejar no limite, não expõe mas, ao contrario, articula.

Essa talvez seja a função mais essencial da arte e sua dimensão utópica, qual seja, articular o inaudível e o invisível, encarnando a questão do sujeito e sua relação à palavra como instrumento de construção. Seria como dizer que através do visível ouvimos o invisível, ou através do audível vemos o silêncio. Ou, ainda, como a escultura, tão densa em sua materialidade, a qual muitas vezes nos possibilita ver o que é imaterial, como, por exemplo, o vento. 
Mas tal operação em uma análise acontece sobre o terreno da transferência, que situa o sujeito numa dupla referência ao Outro. Ao se deslocar do campo da resposta imediata à linha sintagmática da fala do analisante, no analista se justapõem duas posições linguageiras - o tu e o Outro.

Isto provoca profundas consequiências na dimensão do espaço e do tempo.

Na análise, a posição deslocada que o analista deve sustentar quanto ao apelo do eu que lhe fala resulta em que o aqui e o agora perdem sua nitidez e cedem lugar a uma espécie de lusco-fusco da presença-ausência, do presente e do passado.

Nesta operação, certamente, o amor é um elemento essencial como suporte para assegurar que esta experiência de proximidade com a ausência seja suportável.

E será a transferência - este poderoso dispositivo - que sustentará a travessia dessa empreitada, tornando possível a um sujeito assumir o reconhecimento de que é constituído pelo que diz.

E, mais ainda, é o que faz com seja possível o adiamento, continuamente renovado de qualquer resposta ao imediato de seus ditos, instalado pelo reiterado silêncio do analista, que mesmo quando fala não responde.

Estas são as duas referências justapostas, demanda e pulsão invocante.

É a partir da transferência que a fala pode ser reconhecida em sua alteridade radical.

Por este caminho pode-se dizer que o poeta fica instalado num ponto de ultrapassagem da demanda, referido ao Outro ausente, situado no devir.

Neste ponto o analista coloca ao artista uma questão sobre a dimensão ética de sua palavra construída no para além desse outro, sem ter de, necessariamente, levá-lo em conta.

Esta questão parece estar produzindo muitos efeitos.

Não é raro encontramos atualmente produções artísticas que representam tentativas do artista de evidenciar a dimensão ética de sua 
produção. Vemos, por exemplo, telas compostas também com palavras, conduzindo chamamentos éticos.

Drummond parece atento a esta questão:

São muitos, em sua vasta obra, os poemas que falam da própria palavra, sublinhando seu poder e sua função.

Em A palavra mágica dirá:

Certa palavra dorme na sombra

De um livro raro.

Como desencantá-la?

É a senha da vida

A senha do mundo.

Vou procurá-la.

Vou procura-la a vida inteira

No mundo todo.

Se tarda o encontro, se não a encontro

Não desanimo,

Procuro sempre.

Procuro sempre, e minha procura

Ficará sendo minha palavra.

Penso ser esta a direção que deve ser seguida pelo trabalho analítico - a arte e sua ética.

\section{REFERÊNCIAS BIBLIOGRÁFICAS}

Andrade, Carlos Drummond de. Antologia Poética. 48. ed. Rio de Janeiro: Editora Record, 2001.

Didier-Weill, Alain. A nota azul. [sl, sd].

Lacan, Jacques. O seminário, livro 8 - A transferência. Rio de Janeiro: Zahar, [sd]. 